Portland State University

PDXScholar

\title{
A Corpus Approach Study on the Manzanar Free Press
}

Danielle Jochums

Portland State University

Follow this and additional works at: https://pdxscholar.library.pdx.edu/honorstheses

Part of the Anthropological Linguistics and Sociolinguistics Commons, Applied Linguistics Commons, Discourse and Text Linguistics Commons, Race and Ethnicity Commons, and the Social Justice Commons

Let us know how access to this document benefits you.

\section{Recommended Citation}

Jochums, Danielle, "A Corpus Approach Study on the Manzanar Free Press" (2021). University Honors Theses. Paper 970.

https://doi.org/10.15760/honors.994

This Thesis is brought to you for free and open access. It has been accepted for inclusion in University Honors Theses by an authorized administrator of PDXScholar. Please contact us if we can make this document more accessible: pdxscholar@pdx.edu. 
A corpus approach study on the Manzanar Free Press

Danielle Jochums

Portland State University 


\begin{abstract}
Past studies on the physical environment of the Japanese-American internment camps of World War II have argued that internees were able to express their agency and identity despite the dehumanization of the camps. However, studies on the newspapers circulated in the camps have argued that internees had no agency as they worked on newspapers. In a preliminary reading, it was clear that these newspapers evidenced internee agency in their language. Utilizing de Certeau's theoretical framework of tactics, this study addressed the following questions: What tactics did Japanese-American internees use to take agency when writing and editing camp newspapers? How did the tactics relate to their Japanese-American identities? What discursive techniques were represented in the tactics? This study utilized a corpus-based approach to Critical Applied Linguistics. The corpus was assembled from Manzanar Free Press issues. Using Key Words in Context searches, the terms allegiance, loyalty, and justice were analyzed qualitatively in context. Japanese-American staff of the Manzanar Free Press included the discursive techniques like selective quoting patterns, hedging, and emotional distancing and included content complicating notions of an essentialized Japanese-American identity. Using these discursive strategies, they engaged in this tactic of storytelling successfully, seizing agency and maintaining their identities. Otherwise voiceless, Japanese-American internees used the space of the Manzanar Free Press to engage in complex narrative development. Internees used not just the built environment, but also language to maintain agency and identity. This maintenance shows the marginalized can use narrative development to claim power.
\end{abstract}




\section{Introduction}

How do Americans who have their rights completely taken away from them maintain and express their identities? This question has been unfortunately relevant throughout U.S. history and in the present. One case of identity maintenance in the face of injustice that stands in ignominy is the Japanese-American internment camps of World War II. Despite these injustices experienced by internees, previous scholarship on these camps has demonstrated the internees were able to undermine the reductive necropolitical power of the internment in their adaptations of the material space of the camps. However, the question of how internees adapted to and adapted the linguistic space of the camps remains unanswered as it has, surprisingly, never been analyzed in the field of Critical Applied Linguistics. Applied Linguistics draws on theoretical linguistics as well as fields such as sociology, cultural studies, and psychology in order to understand how language is utilized in context. Furthering this, there is the field of Critical Applied Linguistics, about which Pennycook (2001) states that one "might say that critical here means taking social inequality and social transformation as central to one's work" (5). This study intends to apply the principles of Critical Applied Linguistics to the context in the JapaneseAmerican internment camps, seeking to add a much-needed linguistic perspective to the academic discussions of the internee-run newspapers and of exercises of agency and identity construction among internees using the theoretical lenses of necropolitics and tactics. Utilizing a corpus approach, it seeks to further contribute to current understanding of how disempowered populations can utilize participation in specific discourses in order to agentively co-construct their identities. 


\section{Background}

On February 19, 1942, President Franklin D. Roosevelt signed Executive Order 9066, authorizing the mass incarceration of more than 110,000 Japanese-Americans in 10 relocation centers in the continental U.S. By the spring of that year, virtually the entire population of those of Japanese ancestry in California, Oregon, and Washington were forced out of their homes, only able to take what they could carry with them. Initially these men, women, and children were housed in makeshift assembly centers, often living in fairgrounds and being quartered in livestock stalls. After this, they were taken via shuttered railroad cars to their official relocation centers. These relocation centers were hastily constructed camps in inhospitable locations. Often they were not fully constructed at the time that the internees were transferred into the camps. These desolate camps with tarpaper barracks from California to Arkansas were home to 90 percent of all Japanese Americans for all or part of the war years (Kessler, 1998). About twothirds of the internees were American citizens by birthright, born and raised in the United States (Mizuno, 2003) and had no evidence of disloyalty to the United States against them. Despite this fact, the internment was upheld as constitutional in the U.S. Supreme Court Case Korematsu v. United States; the majority decision stated that the internment was a "martial necessity arising from the danger of espionage and sabotage" (1943). And so, from 1942 to 1945, the majority of Japanese Americans were unjustly interned in camps, denied their basic human rights, and subjugated to the rule of the War Relocation Authority (WRA).

Despite the dehumanizing nature of the camps, internees found ways to build community and maintain their sense of agency within the context of the internment. In her landscape architecture dissertation, Tamura (2002) identifies the ways that Japanese Americans utilized ornamental and Victory gardening as a tool for maintaining their agency, morale, cultural 
identities and social identities as loyal Americans. In a related inquiry, Dusselier (2002) found that internees were able to strategically use food and control of the mess halls' meal production in order to maintain cultural identities and values within the camps. Both inquiries illustrated how Japanese-American internees were able to both adapt to their environment and adapt their environment in such a way that upheld the identities and values they developed before being incarcerated in the camps; these insights into internees claiming agency set a valuable precedent that has been overlooked by other subsets of academic inquiries on the Japanese-American internment camps.

One of these subsets of literature on the internment camps that overlooks internee agency focuses on the newspapers published by internees and circulated within the camps instead of on the material environment of the camps. There have been several historical investigations into these newspapers, mostly focusing on language rights and suppression of freedom of speech. These articles narrow their inquiries to be about policy and expectations, mostly relying on bureaucratic records as opposed to the actual linguistic content of the newspapers. For this reason, they do not reference or analyze the language contained in the newspapers in question. Mizuno (2003) investigates records on WRA policy concerning spoken and written Japanese language, finding that spoken Japanese was banned at large gatherings and written Japanese was only allowed under very strict conditions. Many texts written in Japanese, including classic fiction translated from English to Japanese, were seized and destroyed. Mizuno (2001) also examined WRA policy concerning the publication of camp newspapers, highlighting the importance of having internees run the newspapers as an easy and effective way to efficiently spread information to incoming internees. The first issues of newspapers were often printed before the camps themselves were finished. With at least one newspaper in circulation at every 
camp, the WRA used the newspapers to support claims to those outside the camps that the camps were a place of freedom and tolerance. However, the newspapers were under the supervision of the WRA and strategically monitored. Staffed by Japanese-Americans that had worked in publishing before the internment, newspapers disseminated important information necessary for life in the camps and boosted morale in the camps in order to suppress protests.

In a related article, Kessler (2005) investigated three of these newspapers in order to determine the underlying principles of the reporting coverage. Like Mizuno, Kessler describes the creation of newspapers in the camps as being a way for the WRA to disseminate information and increase morale among internees. However, Kessler focuses on the self-imposed nature of the censorship in the newspapers as reporters and editors for the papers understood that including dissent in any articles would result in losing chances at private employment outside the camps and could result in movement to different, harsher camps. Because of these, newspaper editors often acted as propagandists in support of the WRA by highlighting patriotic duties and the need for obedience while minimizing any negative events or aspects of the camps, including generally refraining from reporting on strikes except to condemn them.

A useful lens to take to inquiries on the internment camps is Mbembe's (2003) conceptualization of necropolitics. Necropolitics builds upon the Foucauldian concept of biopower and assumes that the power to kill or to allow survival constitutes the limits of sovereignty. In this explanation of necropolitics, Mbembe examines several examples of necropolitical power so as to illustrate the nuances included in necropolitical systems. In one example focusing on the death-in-life of slaves on plantations, Mbembe describes the slave as experiencing a triple loss as they lose home, control over their body, and political status. 
However, despite these losses, Mbembe acknowledges that slaves can "maintain alternative perspectives toward time, work, and self" (p. 22). Mbembe furthers this argument, claiming that "the slave (...) is able to draw almost any object, instrument, language, or gesture into a performance and then stylize it" (p. 22). In saying this, Mbembe is pointing to the strategic seizure of aesthetics as a means to maintain selfhood and identity in the face of necropolitical dehumanization. Such strategic seizure of aspects of the environment is exemplified also by the accounts of Dusselier and Tamura in their accounts of food and gardens in the camps.

Another useful theoretical angle in the evaluation of this data is presented in Michel de Certeau's The Practice of Everyday Life. Also leaning on Foucault's Discipline and Punish, de Certeau argues that if Foucault's assertions are correct that discipline is becoming more extensive in the modern world, then it is important to understand what daily actions members of society can enact in order to maintain a measure of control and individuality. As he puts it, "it is all the more urgent to discover how an entire society resists being reduced to it, what popular procedures (...) manipulate the mechanisms of discipline and conform to them only in order to evade them, and finally, what 'ways of operating' form the counterpart, on the consumer's (or 'dominee's?') side, or the mute processes that organize the establishment of socioeconomic order” (p. xiv). In order to guide his inquiry, in his introduction, de Certeau outlines a distinction between what he refers to as strategies and tactics. A strategy, in this framework, is any action taken by those in positions of controlling place and production that further distinguishes the individuals or institutions in those positions. On the other hand, a tactic cannot count on this spatial or institutional localization. A tactic is a seizure of power that depends on temporarily or fragmentarily using the space of controlling entities. De Certeau asserts that "many everyday practices (talking, reading, moving about, shopping, cooking, etc.) are tactical in character. And 
so are, more generally, many 'ways of operating': victories of the 'weak' over the 'strong' (whether the strength be that of powerful people of the violence of things or of an imposed order, etc.), clever tricks, knowing how to get away with things, 'hunter's cunning,' maneuvers, polymorphic simulations, joyful discoveries, poetic as well as warlike" (p. xix). In other words, tactics are usages of moments and actions allotted to the disempowered which can be used to exert agency and individual thought. A school curriculum may dictate a student's mandatory reading material, but it cannot force that student to come to particular thematic conclusions, cannot eliminate the possibility of the student drawing intertextual connections, and cannot prevent the student from imagining a different potential ending. In this example, setting the curriculum is strategic, while reading and maintaining one's right to a subjective experience is tactical.

Both Mbembe and de Certeau propose that those without their own space to assert their power can engage in resistance, even if only temporary, through subversive repurposing of everyday acts. Further, de Certeau argues that these individuals can seize onto opportunities to capitalize on and insinuate tactics into the places of those in power. The tactic depends on time in order to exert its effects over the established spaces of dominating entities. Implied in de Certeau's descriptions of tactics is a Robin Hood quality, using cunning to give to the underprivileged what the privileged have and will continue to have.

Mbembe and de Certeau's work are useful frameworks under which analysis on the historical data and past academic studies can be connected to theoretical understandings of agency and the relation between the disempowered individual in society. While the existing literature on the newspapers of the internment camps provides insight into the policies of the WRA regarding language and newspaper publication, gaps remain in our understanding of the 
newspapers in the internment camps. The first of these is that many of the inquiries are largely focused on the presence of censorship and do not seem to look at the potential for instances of stylization, tactics, or other agentive processes of identity construction within the texts. Dusselier (2002) and Tamura's (2002) work, as well as other articles on aesthetic improvements in the camps, frame the internees as being active agents who seize and utilize spaces in the camps to maintain their multiple identities. The articles on newspapers in the camps, on the other hand, tend not to focus on the agency of internees or tactical seizure of the newspapers; they instead focus more on censorship as opposed to focusing on how internees adapted to or reacted to these policies. Upon preliminary reading of the newspapers, it is clear that the newspapers represented another niche of the environment that the internees could seize upon and utilize in order to fight back against the reductive nature of the necropolitical forces they lived under. Alternatively, it could also be that the newspapers were themselves utilized in order to reinforce and support the necropolitical power of the WRA as the content of the newspapers was a tool of subjugation. In all likelihood, it could be some combination of the two, with both tactics and strategies being put into place, and the same place at that.

A second gap in the existing literature on the newspapers in the internment camps concerns the focus of the studies. Currently, the studies have all been historical or political in nature as opposed to being focused specifically on language use. The study of the newspapers is lacking insights that Critical Applied Linguistics can provide. Like historical or political science studies, applied linguistics studies are able to interpret data in terms of power, identity, and societal expectations. What sets applied linguistics apart is the understanding that language choices reflect the views of the speaker and are a tangible insight into the stance and assumptions of the speaker. 
I am conducting a linguistic investigation of a Japanese American Internment Camp newspaper to the end of filling these two gaps. With the current study, I intend to utilize a corpus linguistics approach to the end of filling the aforementioned gaps in research on internment camp newspapers. With this investigation, I seek to answer the following questions:

What tactics did Japanese-American internees use to take agency when writing and editing camp newspapers? How did the tactics relate to their Japanese-American identities? What discursive techniques were represented in the tactics?

\section{Methods}

\section{The Corpus Linguistics Approach}

In order to research these questions, I used a corpus linguistics approach. Corpus linguistics is an approach in which a principled, naturally-occurring body of text - the corpus is assembled and analyzed with computational software. Corpus linguistics has strength in being able to process large amounts of data faster and more reliably than a human can.

For analyzing the corpus, I used a typical kind of computational software called a concordancer. Concordancers can be used to process data by performing functions like searching for specific terms or finding words that are highly related to each other. Concordancers are therefore an ideal tool for finding patterns in the language that might go unrecognized by human analysis. Employing a corpus linguistics approach will allow for a principled investigation on the language in the Japanese-American internment camp newspapers and effectively mitigate the threat of "cherry-picking" data to confirm the researcher's hypotheses. 
Wilkinson (2019) points out that corpus-based critical discourse analysis "is useful in mapping how identity is linguistically represented and constructed" (p. 250), referring to the work of Baker and McEnery. Baker and Levon's (2015) investigation of masculine identities in the British press found that there were clear relationships between suggestions of criminal and moral tendencies based on the race and class of the men being described. McEnery and Baker (2017) similarly used corpus linguistic methods in order to conduct a historically-oriented inquiry into the language used to discuss prostitution in the $17^{\text {th }}$ century, finding that there were a variety of lexically discreet portrayals of sex work at this time. Wilkinson's own 2019 study looked at decades of change in understanding and representation of those who identify as bisexual, providing insight into how mainstream newspaper media privileges binary notions of sexuality both historically and currently. All of these studies are exemplars of analyzing how identity is mediated through text in both the past and present. Following in these precedents, I seek to evaluate the language of Japanese American internment camp newspapers utilizing a corpus of my own design and compilation.

\section{Corpus Design and Compilation}

I have compiled a corpus of newspapers published in Japanese American Internment camps. As taking a representative sample of all from the available newspapers from the Internment camps would be beyond the scope of this project, I compiled a corpus of texts from Manzanar, a camp that was located in Inyo County, California. Manzanar is a camp that is welldocumented through internee autobiographies and historical scholarship. However, in literature that focuses specifically on newspapers, The Manzanar Free Press has received little attention. Compiling a corpus using The Manzanar Free Press helps fill this gap in the discourse. 
My texts come from the digital newspaper archives of the U.S. Library of Congress. The library has all of the newspaper publications from Manzanar available as PDF files. The collection also features a machine-made transcription of the newspapers. These transcriptions tend to have many inaccuracies as the newspapers can be hard to read at times for both humans and software.

The first available issue of The Manzanar Free Press was published on June 2, 1942 and the last was published on September 8, 1945. With the exception of a few months, The Manzanar Free Press had either three or two issues a week. In 1942, there were generally 3 issues per week. However, by January 1943, the paper had transitioned to two issues a week. December was generally the most variable month, with as few as three issues released for the entire month. The average issue is $6-8$ pages with about 8,000 words per newspaper issue.

I wanted the texts of my corpus to span the full timeline of the camps, so the texts were obtained using a stratified sample. I selected one newspaper issue from each of the 40 months that The Manzanar Free Press was in operation. For the selection of what article to pick from each month, I assigned each issue a number, starting with the first issue of the month being 1, the second issue being 2 , and so on. I then made the selections by utilizing a random number generator.

Once the texts were selected, I extracted the machine-generated transcription of each text from the Library of Congress. The transcriptions were checked against PDF scans of the original newspapers and transcription errors were corrected. After determining accurate transcription of the newspapers, I made edits to all the text files in order to assure that only the content of the newspapers appears in the corpus, removing the parts of the newspaper including lexical items 
like the reoccurring "Manzanar Free Press" at the top as well as page numbers and issue numbers. This corpus includes 240,300 words.

\section{Analytic Procedures}

After compiling my corpus, I completed my analyses using the widely-used free concordancer AntConc 3.5 Software. As my analyses are largely preliminary investigation, I have used basic corpus techniques modelled off of past research on identity representation and construction in language that utilize critical discourse analysis techniques and corpus-based approaches. In particular, I adapted the techniques of Bock and Hunt (2015) for my study. Their study focused on the usage of pronouns in interview groups discussing South Africa's past and current affirmative action-type programs in universities. They utilized Key Words in Context (KWiC) searches in order to determine the amount of times each interview group used inclusive and exclusive pronouns, such as they and we. $\mathrm{KWiC}$ searches display the search terms within concordance lines, or a specified window of context, and allow researchers to quickly identify the number of times a word appears in a corpus and what contexts the word is generally found in. After this search, qualitative research was done to determine what discursive techniques, including the strategic usage of pronouns, were used in order to show in-group or out-group status.

In my KWiC searches, I looked for specific terms that seem to be central to identity expressions. I have created a list of content words that relate to the identity and attitude of the internees. This list was decided upon by consulting past research, expert contacts, and issues of the newspapers themselves. At the beginning of my project, I investigated the words in the key terms listed in Table 1. 
Table 1. Words related to identity in the newspapers

\begin{tabular}{|l|l|}
\hline Grouping & Words \\
\hline Ethnicity & Japanese, Japan, Jap, American, America, United States, Nissei, Issei, citizen \\
\hline Policy & War Relocation Authority (WRA), military, administration, strike, relocation \\
\hline Religion & $\begin{array}{l}\text { Buddhist, Shinto, Christian, temple, shrine, chapel, church, ancestor, } \\
\text { meditation, prayer, priest, pastor, minister, Bible, God }\end{array}$ \\
\hline $\begin{array}{l}\text { Abstract } \\
\text { concepts }\end{array}$ & $\begin{array}{l}\text { Responsibility, duty, allegiance, loyalty, justice, honor, cooperation, } \\
\text { assimilation, perseverance, privacy, cleanliness, patriotism, gaman }\end{array}$ \\
\hline
\end{tabular}

For the majority of these words, I input my searches so as to get results that have the same base concept. For example, the item loyal would include results such as the nominalization loyalty.

This list was updated as I worked with the data, as this explorative interplay between the data and the methods is a benefit of corpus linguistics. The list was narrowed as I worked with the data and decided which groupings should be the focus of my present study.

In order to narrow down which search terms would form the core of my qualitative analysis, I conducted a preliminary analysis of the terms. In order to do this, I utilized the Key Words in Context function in order to obtain a quantitative breakdown of how often the search terms were used. I then read the concordance lines to determine what information, problems, and complications their concordance lines showed. The raw counts of these words, followed by brief description of surface-level patterns that were evident based on the concordance lines, are organized by ideational category and listed tables 2 - 4 .

Table 2. Raw counts of search terms related to ethnicity

\begin{tabular}{|c|c|c|c|c|c|c|c|c|c|}
\hline \multicolumn{10}{|c|}{ Ethnicity } \\
\hline Term & Japanese & Japan & Jap & American & America & $\begin{array}{l}\text { United } \\
\text { States }\end{array}$ & Issei & Nisei & Citizen \\
\hline $\begin{array}{l}\text { Raw } \\
\text { Count }\end{array}$ & 769 & 36 & 7 & 20 & 39 & 121 & 49 & 260 & 76 \\
\hline
\end{tabular}


The data on these ethnicity search terms presented an interesting quantitative issue. Many of the words were utilized in phrases that actually made them operationally the same as a different term. This was true of phrases such as Japanese-American, Americans of Japanese Descent. Because of this, it is often difficult to parse without thorough reading of the articles whether the searches are identifying different groups or entities.

Issei and Nisei, on the other hand, rarely have overlap with other groups or entities. These terms refer to generational immigration distinctions, with Issei being the first generation in the U.S. and Nisei being born in the U.S. These terms are often used in personal ads, employment ads, and reporting articles. Nisei is especially frequently seen when reporting on JapaneseAmerican military activity.

Table 3. Raw counts of search terms related to policy

\section{Policy}

\begin{tabular}{|l|l|l|l|l|l|}
\hline Term & $\begin{array}{l}\text { War } \\
\text { Relocation } \\
\text { Authority } \\
\text { (WRA) }\end{array}$ & Military & Administration & Strike & Relocation \\
\hline Raw Count & 250 & 78 & 13 & 8 & 478 \\
\hline
\end{tabular}

In these searches, there were issues with homophones, with the word strike most frequently referring to a baseball strike. However, the other terms in this data set did occur, to varying extents, with frequency. From the concordance lines, it appeared that these terms were generally used in reporting articles with not much opinion included. Rather, the lines demonstrated a reporting of logistical information, policy updates, and names of officials.

Table 3. Raw counts of search terms related to religion 


\begin{tabular}{|l|l|l|l|l|l|l|l|}
\hline Religion \\
\hline Term & Buddhist & Shinto & Christian & temple & shrine & Chapel & Church \\
\hline $\begin{array}{l}\text { Raw } \\
\text { Count }\end{array}$ & 36 & 2 & 28 & 7 & 2 & 1 & 95 \\
\hline
\end{tabular}

\begin{tabular}{|l|l|l|l|l|l|l|l|l|}
\hline Religion & Mediation & Prayer & Priest & Pastor & Minister & Bible & God \\
\hline Term & Ancestor & Maw \\
Count & 0 & 0 & 6 & 1 & 6 & 8 & 0 & 9 \\
\hline
\end{tabular}

The terms Buddhist and Christian are used frequently to describe activities or services held by members of those religious groups. The term Shinto is much less present in the corpora, with only one entry referring to Shinto as a religion as opposed to a surname. When it comes to temples, shrines, and chapels, these words are very infrequent, especially after you adjust for the surname Temple. Church, in contrast, occurs more in the corpus. Church is used when referring both to Buddhist church services and Christian Services. Furthermore, many denominations of Christianity appear in the concordance lines for this search term. It is clear that Christian church activities both inside and outside the camps are discussed when looking at the context of the concordance lines.

The other search terms in this category occurred quite rarely in this corpus, with ancestor, meditation, and Bible surprisingly not occurring at all.

Table 4. Raw counts of search terms related to concepts

\begin{tabular}{|l|l|l|l|l|l|l|l|}
\hline Concept & \multicolumn{2}{|l|}{$\mid$} \\
\hline Term & Cleanliness & Cooperation & Assimilation & Gaman & Perseverance & Privacy & Patriotism \\
\hline $\begin{array}{l}\text { Raw } \\
\text { count }\end{array}$ & 1 & 40 & 0 & 0 & 0 & 1 & 1 \\
\hline
\end{tabular}




\begin{tabular}{|l|l|l|l|l|l|l|}
\hline Concept \\
Term & Responsibility & Duty & Honor & Allegiance & Loyalty & Justice \\
\hline $\begin{array}{l}\text { Raw } \\
\text { count }\end{array}$ & 14 & 29 & 30 & 4 & 38 & 26 \\
\hline
\end{tabular}

As was the case with words in the religion category, several of these search terms occurred either not at all or too rarely to establish trends about. This is further complicated even in words that do occur more often in the corpus because some of these raw counts are inflated. Some occurrences of these terms are used not in the abstract sense of an ideal, but instead are used in set expressions. Such is the case with honor, which is almost always including in the phrase Maid of Honor in wedding announcements, and duty, which is used when referring to active duty.

Three of these search terms brought up articles that directly addressed issues of politics and identity: loyalty, injustice, and allegiance. Allegiance, while not occurring very frequently in the corpus, was a search term that brought to the forefront the questions of loyalty and national identity. Generally, its occurrences were isolated to discussion of loyalty questionnaires that were mandatory to fill out in the camps. Loyalty and injustice, in contrast, noticeably were used in much wider discussions of life inside and outside the camps.

While all of this data presents valuable insights into internee identity and perspective on camp life, it is outside of the scope of the current study to do qualitative analysis on each term. Because of this limitation, I chose to concentrate my qualitative analysis on three terms for the current study: allegiance, loyalty, and injustice. I selected these terms in particular because as I was looking through the concordance lines on these terms, I saw patterns that merited more 
comprehensive exploration. Further, both of these concepts underscore the experience and existence of the Japanese-American internment camps themselves.

\section{Results}

This results section is composed of two parts: an overview of the content and formatting of the newspapers, and a deeper look into three specific terms and their variations - allegiance, loyalty, and injustice. In the second section of the results, I will qualitatively analyze the data brought up by the KWiC searches of these terms and their variations. In so doing, I will identify patterns in discursive techniques and identity construction processes, and present illustrative concordance lines.

\section{The Newspapers}

As I read all of the newspapers in this corpus, in this section I will report on general formatting and content trends that were obvious patterns throughout the newspapers; this will provide an orientation to the data that will situate the qualitative analysis. As previously stated, the newspapers were generally $6-8$ pages, with the exception of occasional special issues. The final page of the newspaper was always dedicated to sports events in the camps, such as the baseball games of the internee teams. The first page generally reports on the most current events. The second page almost always includes a column on an accomplishment of Japanese-Americans or a reprint of a different newspaper that supports Japanese-Americans. The newspaper also includes schedules for events, such as religious services, personal ads, ads from retailers inside and outside the camps, and humor and gossip columns.

\section{Allegiance}


The term allegiance occurs 4 times in this corpus. Of these occurrences, each one refers to swearing allegiance to the United States or denying allegiance to the Japanese Emperor and is reporting on legal action at the federal level. Three of the occurrences provide information on legal measures proposed by the Attorney General, while one reports on a congressional committee.

Although the number of occurrences for this search term is small, the concordance lines include a discursive strategy that is common throughout the results of this study quoting patterns that value Caucasian-American voices. In a September 1943 issue of the Manzanar Free Press, an article on the Dies Committee published in the Chicago Sun is reprinted. The article reports the following:

Some Japanese moved from the West Coast were dangerous aliens, but tens of thousands were American citizens, devoted to democracy and having no allegiance to Japan's emperor. The emotional fury burning against them was intensified in the West by the economic motives of Anglo-Saxons who wanted to get rid of competition.

This excerpt, and the entire article from which it was taken, shows a conviction in accusations against Anglo-Saxons that, in this entire corpus, is never seen coming from a Japanese-American speaker. The editors of the Manzanar Free Press are able to give a voice to their oppositional thoughts that they know to be true to their narrative and experience without the consequences that would come from writing these views themselves, or even adding additional supportive commentary to the articles of Caucasian-Americans. They are able to show $a$ perspective and an Anglo-Saxon perspective at that, without making assertions of the validity of that perspective. While this example shows how reprinting Caucasian-American speakers can be used to make 
social commentaries that challenge those in power, this discursive technique was used in the vast majority of Manzanar Free Press issues at least once. Examples of other nuanced ways this discursive technique was used will be explored more in the following sections.

Loyalty and Disloyalty

The term loyal occurs 37 times in this corpus, while disloyal occurs 12 times, loyalty 38 times, and disloyalty 2 times. Loyalty and disloyalty often comes up in the corpus as it relates to questions and discussions of allegiance and legality. Most notably, these KWiC terms often occur in articles concerning an infamous questionnaire administered to internees which sought to assess the internees loyalty and allegiance to the United States of America.

In these discussions, Caucasian-American voices are often elevated through the practice of reprinting journals from outside the camps and from featuring quotes from CaucasianAmericans concerning Japanese-Americans. A prime example of this comes from an April 1945 issue of the Manzanar Free Press in the following lines:

In speaking of the loyalty and courage of Japanese American soldiers, Brown, who has traveled 200,000 miles to entertain servicemen in every theater of war, said, "Why can't they (Americans of Japanese ancestry) be accepted as American?"

In lieu of making direct defenses against discrimination, or, in this case, asking to be accepted as American outright, the Manzanar Free Press editors rather find material that does it for them. This allows them to have agency in the discussion by piecing together narrative that supports their side while also allowing them an ability to fade into the background. They do not selfpromote their own loyalty, but rather select others to do so for them. In the context of having this be published in an internment camp newspaper, this accomplishes a few things. First of all, it 
allows them agency to communicate and narrate the story of their loyalty despite the environment of discrimination. Secondly, it includes, for anyone who is not an internee, evidence of Japanese-American loyalty from a perceptive that they would respect. Third, it allows the editors to give the internees some amount of assurance that public opinion outside the camps is not completely against them. All of these are examples of how the editors could agentively utilize the voices of those outside the camps in order to establish Japanese-American loyalty and provide a counter narrative to the Japanese-American subversive and spy.

When Japanese individuals are quoted, the discursive technique of distancing is involved. For instance, this quote by a Japanese-American mother of a soldier is included in the Manzanar Free Press, but only after it was printed in the Milwaukee Journal.

“(...) This is their home, and my sons are working toward the betterment of their motherland and fighting endlessly to win their place in the United States as loyal citizens whose faith in America will not die, and will grow even stronger. My son, Arnold, proved that by sacrificing his life on the Italian front”.

This was followed by commentary from the Caucasian-American reporter:

"Do you know of any American, especially an American in so difficult a position, who has put it better?"

These excerpts demonstrate two types of the discursive technique of distancing. The first follows in the pattern of including and valuing white voices and insights; the editorial decisions and commentary of a Caucasian-American are what allow a direct quote from a Japanese-American to be featured. In reprinting this article, the editor of the Manzanar Free Press does not make 
any assertions on Japanese-American loyalty directly, but rather relies on the commentary of an outside voice to do so.

A second discursive technique utilized in these excerpts was minimization of emotional turmoil. Instead of emphasizing the grieving element, this quote emphasizes the message that Japanese-Americans are loyal citizens. While the quote from Arnold's mother obviously features the loss of her son, the grief is foregrounded in favor of highlighting Japanese-American faith and sacrifice for the United States. The quote is stoic and patriotic almost to the point of dogmatism, excluding the wrongs of the country her son is serving in a show of unyielding loyalty to the motherland.

This example of minimized emotional turmoil is contrasted by another direct quote pertaining to loyalty from an honorably discharged soldier residing in Chicago after his suicide attempt. The Manzanar Free Press reports:

It said that Oda slashed his arm three times with a razor after writing a note reading: "I am a good, loyal American. Honest to God, I am no spy or the things they say. Please believe me. There will never be peace anywhere for me."

This quote, like that by the mother of Arnold, focuses on being a loyal American. However, due to the context and the tone of desperation in the embedded quote, the emotional turmoil that the loyalty question causes is clearly evident. Although this article is short, being just a few sentences longer than the lines above, it is one of the few examples of the extreme distress felt by Japanese-Americans in this period that is not glossed over or minimized. It shows how detrimental the question of loyalty could be to a Japanese-American's identity and sense of self in this time period. Its inclusion in the newspaper thus represents the existence of impactful, 
though less commonly used discursive techniques. Thus, both the inclusion of the quote by Oda and by Arnold's mother demonstrate a nuanced discursive relationship between displays of emotion and loyalty to the U.S. Giving space to these nuances in the Manzanar Free Press represents an infrequent, but interesting discursive technique of showing a range of emotional reactions to accusations of disloyalty.

However, these search terms do not just bring up questions of loyalty. By sorting through the concordance lines, one can also see a more subtle question of group membership and identity. This question appears in several ways and several forms throughout the articles, although they cannot be pinned down by a particular discursive technique. The remainder of the excerpts in this section show that content that broadened and complicated the portrayal of Japanese-American identity was included in the Manzanar Free Press, even if these excerpts do not fall in the purview of discursive techniques.

First of all, there is a question of being American and having loyalty to the U.S. This question is a clear factor in the above concordance lines, but is also seen in nuanced ways in other places as well.

In a June 1944 article on California measures being voted on by those outside the internment camps, there is discussion on how loyalty relates to being an American and citizenship. Although the internees could not vote on these measures, they would profoundly affect the lives of the internees upon their release from the camps. One concordance line of particular interest from these discussions goes as follows:

This measure would amend the alien land law of 1920 and would provide for voting restrictions against what are termed "disloyals"; actually, those with dual citizenship. 
This quote shows the discriminatory linguistic encoding that was happening in this period.

Disloyalty, an abstract concept of devotion, was being given a legal operationalization as being anyone with dual citizenship. In other words, having any documentable connection to another country was not only being penalized by the threat of having constitutional rights stripped away in this country, but was also receiving an ideational label of going against the United States itself. This instance of conflation shows that assertions of loyalty and disloyalty had effects that extended outside of the camps and outside of personal interest pieces. This shows that identity co-construction processes occurring at this time had the potential to have long-lasting effects on the lives of Japanese-Americans. It also demonstrates that discussions of disloyalty inside and outside the camps impacted their agency in matters of legality and social identity.

While notions of identification and loyalty were being manipulated against the favor of Japanese-Americans, these notions were also manipulated in their favor and support. An interesting case in complicating questions of loyalty and belonging is the story and quotes from Ralph Lazo, a Mexican-American man who registered as Japanese-American in order to remain with his Japanese-American friends. The following excerpt is from an August 1944 issue of the Manzanar Free Press which interviewed Lazo on why he chose to be an internee:

"I cast my lot with the Japanese Americans because I did not believe that my friends of Japanese ancestry were disloyal to the United States," he said. "so I decided to go along with them. Who can say I haven't got Japanese blood in me? Who knows what kind of blood runs in their veins?"

This quote effectively undermines the claims that those of Japanese ancestry are disloyal to the U.S. and undermines the notion of race itself. It accomplishes the first of these by indicating that 
he valued his connection of his friends of Japanese ancestry, trusted his knowledge of these friends, and felt a sense of loyalty to them to the extent that he was willing to "cast his lot" and endure whatever discrimination and hardship they faced. This in and of itself is a powerful demonstration of trust and support on the part of Lazo. But he furthers this by complicating the idea of profiling and discrimination, highlighting how arbitrary understandings of race and ethnicity often are. He phrases this by asking his audience how they can know that he isn't Japanese. In so doing, he emphasizes the importance of identity, decision, and loyalty over strict genetics. The editors' decision to include Lazo's story and words demonstrates a desire to use the stories and experiences of allies in order to complicate notions of identity and loyalty.

A trend of interest that appears when investigating Japanese-American internees' rhetorical relationship with loyalty and disloyalty is the reoccurrence of discussion on how much homogeneity exists under the label of Japanese-American. This is explored and discussed through the internees' discussion of other internees who are disloyal or subversive.

In an issue written towards the end of the internment, in January of 1945, a Manzanar Free Press journalist reflects on the beginning of the internment camps and how they came to be. He frames the internment as being economically and racially motivated, although he gives the following acknowledgement:

There were a few disloyal Japanese, to be sure.

However, he goes on to discuss how none of the internees were ever formally charged with espionage or sabotage. This fits in with a larger pattern in the data found containing these search terms wherein the possibility of Japanese-American disloyalty or presence of disloyals is sometimes acknowledged, but only very briefly before continuing at the argument that at least 
the vast majority of Japanese-Americans are loyal to the U.S. This is tactful in that it does not undermine or go against the U.S. government or the WRA, but also furthers the narrative of Japanese-American loyalty. It does bring into question how many disloyal Japanese-American individuals there are and refrains from making overly broad claims about all internees, calling into question the homogeny of the group.

Additionally, in a more subtle way, the above excerpt also brought into question through the generational and social classification utilized by the internees. As mentioned briefly in the preliminary search section of these results, labels such as Nisei and Issei are used frequently. The Issei were first-generation Japanese immigrants to the U.S., while the Nisei were born in the U.S. and were citizens. There was also another classification, Kibei, which refers to individuals who were born in the U.S., but educated in Japan. The Kibei were often considered to be outsiders.

National WRA Director Dillon Myer made a statement emphasizing these negative attitudes toward kibeis. However, in a notable December 1943 article targeted for Director Dillon Myer, a Manzanar Free Press reporter defends kibei internees, saying:

The inference drawn from Mr. Myer's statement was that all kibeis, irrespective of whether they are at Tule Lake in the relocation projects, or relocated, are "maladjusted social outcasts." This is an impression we would have the director reconsider on a basis of a more complete study of the composition of evacuees as a whole. There are good isseis and kibeis and niseis, and undesirable isseis and kibeis and niseis.

This statement highlights the contours of Japanese-American social classifications, undermining the essentalization of kibeis and, in so doing, undermining the essentialization of JapaneseAmericans as a whole. Note here that the claim is not that all Japanese-Americans are good, 
isseis, kibeis, and niseis, included. Rather, the writer of this article is urging the director to not describe the population in sweeping strokes, but actually understand the variation among internees.

This statement is especially interesting because it does not seek to build the case that all Japanese-Americans are loyal. Rather, it is evidence that the editors use this paper not only to print articles in defense of their American patriotism, but also articles that show the diversity of and uniqueness of the Japanese-American identity. This article seeks to show unity and solidarity between kibeis, isseis, and niseis, but it also seeks to differentiate them and show the variation that exists even within those social categories.

For a quantitative breakdown of how often the term is used in the various discursive techniques mentioned or in order to illustrate more about Japanese-American identity, see the table below.

\begin{tabular}{|l|l|l|l|l|l|}
\hline $\begin{array}{l}\text { Discursive } \\
\text { technique }\end{array}$ & $\begin{array}{l}\text { Selective } \\
\text { quoting } \\
\text { patterns }\end{array}$ & $\begin{array}{l}\text { Emotional } \\
\text { distancing }\end{array}$ & $\begin{array}{l}\text { No clear } \\
\text { technique }\end{array}$ & $\begin{array}{l}\text { Identity } \\
\text { grouping }\end{array}$ & N/A \\
\hline $\begin{array}{l}\text { Number of } \\
\text { occurrences }\end{array}$ & 43 & 5 & 10 & 20 & 5 \\
\hline
\end{tabular}

\section{Justice and Injustice}

The KWiC terms justice and injustice are noteworthy in that these words almost always have contexts related toward discrimination and / or anti-Japanese sentiment. Searching for the term justice in this corpus yields 26 hits, while searching for the term injustice yields 5 hits. In this corpus, justice is used in two senses, the abstract ideal and the title. Justice is frequently collocated with department, as in the Department of Justice. Whether the word occurs in this 
context, in the context of being a title, or the context of being an ideal, the content of the concordance lines almost always relates to discrimination, anti-Japanese sentiment, and the law.

\begin{tabular}{|l|l|l|l|}
\hline Usage & $\begin{array}{l}\text { Collocated with } \\
\text { Department }\end{array}$ & As a title & As an abstract ideal \\
\hline $\begin{array}{l}\text { Number of } \\
\text { occurrences }\end{array}$ & 13 & 4 & 9 \\
\hline
\end{tabular}

Upon reading the articles in which these terms occur, it is clear the trend of the article writers using Caucasian-American opinions or rulings continues in the data surrounding these search terms; Manzanar Free Press staff uses these opinions and rulings to assert the injustice of the internment instead of claiming it outright from their own point of view.

Following this principle, the editors of the Manzanar Free Press often included reprints of newspapers from outside the camps that featured an article in support of Japanese-American citizens. An example of this comes up in our justice search, in the following excerpt from the Chicago Sun reprinted in one of the camps April 1944 issues:

Someone with a sense of justice ought to arrange for Pfc. Hoshinoa Omiya, whose eyes were blown out in Italy, to appear before the congressional committee where honorable gentlemen from the West Coast states are heating up the atmosphere with demands for legislation expediting deportation of American citizens of Japanese ancestry.

This effect of emphasizing Caucasian support is doubled when justice occurs in the corpus as a trend. Take for example this reprint from the Philadelphia Record printed in an August 1945 issue of the Manzanar Free Press: 
We salute Justice Mile Dye. of Walnut Grove, Calif. He has sentenced a woman to 30 days in the Sacramento county jail for threatening a Japanese American soldier and his family.

Reprinting this invokes several layers of authority: that of the Caucasian staff of the Philadelphia Record, that of the Caucasian justice, and, through him, of the justice system itself.

The aptness of this discursive technique is given additional clarity through instances of administrative bodies asking that those being interned have letters of recommendation written by friends and preferably Caucasians if they want their cases to be reheard by the Department of Justice.

When the writers do directly address the idea of justice or injustice, it is hedged in some way, either temporarily, lexically, or discursively. Take for example this concordance line from a January 1945 article on internees receiving permission from the War Department to return to their homes:

A step thus is taken toward righting a gross violation of civil liberties, but more than this is necessary before justice is fully done.

This sentence showcases a direct and assertive stance towards what civil liberties and justice the internees deserve. However, it should be noted that such a strong stance was taken by the writer after the War Department had begun to rectify its transgressions, not before or during. This allows for some temporal distance from the initial issue of the internment camps. This statement is not arguing against the current actions of the War Department, but rather furthering the ideas and supporting the preexisting trajectory of resettlement set by U.S. government institutions. 
Take, in contrast, this concordance line from an earlier issue in August 1942:

Despite the seeming injustice of evacuation and other obvious flaws in this democracy, it is a hundred times more preferable to the stifling darkness of a fascist Japan.

This line, as opposed to the one before it, uses more lexical hedging, with phrases like "seeming injustice of evacuation" as well as discursive minimization of the injustice and flaws of democracy like contrasting U.S. flaws in democracy with the lack of democracy in fascist Japan. These writing choices, which occur at various points throughout the corpus, effectively minimize how serious the injustice and flaws should be judged to be.

Another example of minimizing the seriousness of injustice occurs in the April $1^{\text {st }}$ issue of 1944. In a social news and humor article, following a paragraph that was printed upside down, the writer introduces information on social life in the Tule Lake Camp, writing:

From the Department of Injustice in Tule Lake project comes the following report pertaining to everything in general up yonda...

This line refers to the Department of Justice's takeover of the Tule Lake Camp and clearly shows the writer's negative stance toward the Department of Justice. However, this subversion can easily be dismissed as it is amidst goofs and gossip, hidden among layers of humor. Note the casual nature of the writing, with words written to evoke their spoken pronunciation. This usage of humor to cover divisive opinions was peppered throughout the corpus in a variety of search terms. By embedding the negative views toward a government organization in a humorous context, the subversive nature of the writing is hidden.

\section{Discussion}


Upon looking at the corpus data exemplified in the results section above, it is important to evaluate the patterns that exist in the data, how they connect to the preexisting scholarly work, and how they answer the research questions of the present study. In this discussion section, I seek to resolve the research questions presented in the introduction:

What tactics did Japanese-American internees use to take agency when writing and editing camp newspapers? How did the tactics relate to their Japanese-American identities? What discursive techniques were represented in the tactics?

In answering the first of these questions, I argue that, despite having their normal lives, language, and voices taken from them, Japanese-American Manzanar Free Press writers and editors utilized the tactic of storytelling to seize agency. This was not storytelling in the sense that perhaps first comes to mind; it was not the creation or transmission of a fiction. Rather, the writers and editors engaged in a complex kind of narrative development, using the space of oppressors to circulate the experience of their oppression.

This complexity of this narrative development came to fruition from a tactful arrangement of seemingly contradictory aspects. The writers and editors of the Manzanar Free Press struck a delicate balance of at once executing the strategies of the WRA and the tactics needed by the internees. This is accomplished by attending to two different, but sometimes overlapping wills. First, there is the will of the WRA to disseminate information and to keep morale up to the end of keeping the camps peaceful and productive. This aspect of the newspaper's agenda was elaborated upon by both Mizuno (2001) and Kessler (2005). Second, there is another will present in these papers that it would be a mistake to overlook: the desire and demonstration of agency, independence, and identity maintenance. These were noted in the 
arguments made about the physical environment by Dusselier (2002) and Tamura (2002), but I argue that it is no less present in this textual environment.

Granted, the internees had extreme limitations placed on their freedom of expression and, consequently, their freedom to openly demonstrate their agency and identity. Their limitations were serious obstacles regardless of whether they were imposed through administrative censorship, as Mizuno (2001) argues, or self-censorship, as Kessler (2005) argues. However, internees were still able to utilize this opportunity in order to develop a narrative of their experience that allows them to show the problems they faced, allowed them to show their identification and feelings with regard to the U.S., and allowed them to complicate notions of identity and categorization altogether. The concordance lines explicated in the above section show internees find solace in other reporters outside the camps defending their loyalty, go to the defense of kibeis being described as categorically bad, and discuss ongoing anti-Japanese discrimination within the text of the Manzanar Free Press. They report on selected events from the outside, reprint words by allies, and write their own nuanced and quietly subversive arguments.

In line with Mbembe (2003), they are drawing in the information and the duty of seeing through the task assigned to them by the WRA and stylizing the end product. They are making cohesion and forming patterns to tell their story. Not afforded the resources or place to make their own free tapestry of story, they instead quilt together pieces in the closest reconstruction of their vision that they are allowed. They are far from mindlessly disseminating WRA bulletins and propaganda. Instead, they bring together a variety of different narrative threads, expressing their agency in shaping their story and understandings. 
Of course, this narrative is not as overt or radically subversive as it could be in other circumstances. Manzanar Free Press writers rarely speak out against the WRA, with the exception of politely asking the national director to reconsider his statement on kibei. There is still a venue of strategy; the WRA needed logistical and policy information spread and morale boosted, so it used its resources to print, staff, and, potentially, censor a newspaper. However, a tactic does not need to exist untangled with strategies, but rather often thrives in those spaces. The tactic of utilizing the text of the Manzanar Free Press to quilt together a narrative of Japanese-American internee experience is a demonstration of exercising agency in a sliver of space and time afforded to the disempowered by those in power.

This leads me back to the second of my research questions: how did this tactic relate to their Japanese-American identities? At the first and most basic level, without needing to have read the texts of the Manzanar Free Press, working on the newspaper allowed a feeling of agency and productivity as well as the reclamation of an occupational identity. Just as Tamura (2002) explains that the Japanese-American farmers and gardeners were able to practice their craft and adapt their gardening to a new environment, the writers and editors of the Manzanar Free Press were able to develop or maintain their journalistic skills in the context of the camps. The individuals who started the press worked in newspaper journalism in Los Angeles before being interned. Developing the Manzanar Free Press from a simple bulletin to a full-fledged, triweekly reporting newspaper was a way for them and for the rest of the staff to skillfully use their talents and knowledge to create a meaningful, tangible item for the camp.

This skill was utilized to communicate a number of things about Japanese-American internee identity. This was a newspaper that, while also accommodating the needs and demands of the WRA, was written by internees for internees. Because of this, the Manzanar Free Press 
shows the variety of identities and classifications in the camps and gives some insight into how they related to each other. This variety can be seen in the generational system and the views on kibeis or the contrast between "loyals" and "disloyals", as discussed previously, and other details that were outside the scope of the present study, such as the coexistence of multiple religions and religious institutions.

Further, the Manzanar Free Press showed the variety of reactions that internees had to discrimination. The overwhelming attitude is one of positivity and perseverance; this follows the goal of the WRA to use the newspapers to keep up morale. However, there are instances, such as the article on Oda's suicide attempt, that show the emotional and mental turmoil caused by discrimination and labelling Japanese-Americans as disloyal and un-American. While these tragic reports do not occur in the newspapers very often, they do offer valuable insights into the severe negative emotional effects caused by pervasive lack of acceptance of the American part of the Japanese-American identity.

In contrast to this, the Manzanar Free Press was also an avenue for the internees both to emphasize their loyalty to the U.S. and to see validation of their American identities. The writers and editors of the Manzanar Free Press were able to use the newspaper in order to highlight how the actions of Japanese-Americans inside and outside the camp showed their loyalty to their nation. This, in turn, had an additional effect of possibly furnishing the internees with a greater sense of agency by promoting the narrative that despite, or, perhaps especially because of, their internment, they had the ability and responsibility to do what they could to aid their country in a time of crisis. Despite being ripped from their past lives, their actions still had a weight. What they did would reflect on Japanese-Americans everywhere and show that, regardless of their 
ancestry, they were Americans. Their actions mattered because they showed their value and faith to their country.

However, this practice of using the newspaper to validate the internees' American identities could be construed as something of a double-edged sword. While it emphasized the loyalty and agency of Japanese-Americans, it also conformed to the expectations of racial hierarchy. The usage of incorporating white voices in developing the argument that JapaneseAmericans were loyal was at once a way to provide validation to Japanese-Americans and an identity-conscious show of deference to Caucasian-Americans. This will be further addressed in the final part of the discussion.

The third research question, what particular discursive techniques were used in this tactic of narrative development, remains. In order to construct the narratives discussed above, the editors and writers of The Manzanar Free Press engaged in a wide variety of discursive techniques. Included in the data from the $\mathrm{KWiC}$ searches were a few prominent discursive techniques. The most prominent of these in all of the search terms was the usage of quoting patterns that prioritized Caucasian-American perspectives and voices. Teo (2000) asserts that "the use of quotation becomes a gate-keeping device that admits only those in positions of power and influence while shutting out the opinions and perspectives of those deemed by society to be powerless" (p. 18). This pattern of quotation is not fought against by the writers and editors of the Manzanar Free Press, but rather is tactically capitalized on. Conscious of status and identity, the staff of the Manzanar Free Press follows the societally-accepted norms of media discourse, but scouts out quotations and messages that will lend credibility to their perspectives and identities. They seek out and include validation from those in power, knowing how little weight the opinions and thoughts of the powerless carry. Instead of fighting back against newspaper 
media convention, the staff of the Manzanar Free Press used the quotes from CaucasianAmericans to demonstrate the existence and backing of allies in power, possibly with the intention of garnering more allies or adding substance to the validity of their narratives.

Additionally, hedging, humor, and timing were utilized to voice opinions while minimizing critical or contrary aspects of the commentary. This minimization adds to the success of the narrative construction tactic in that it allows for the continued access to the space of the newspaper that the tactic utilizes and inhabits. More overt criticism and subversive elements would negate the success of the tactic in that they would be censored or Japanese-American contribution to the newspaper would be eliminated altogether. This exemplifies a victory of the "weak" over the "strong" named by de Certeau (1984): knowing how to get away with things. Hedging, humor, and timing allow the Japanese-American article writers to imply or directly say what they want to say both without full discursive effect and without the full negative consequences, ensuring the longevity of the tactic of narrative development.

\section{Conclusion}

Using the discursive techniques of selective quoting patterns, hedging, humor, and emotional distancing, Japanese-American internees satisfied War Relocation Administration mandates while engaging in the tactic of narrative construction, allowing them to use the space of the newspapers to take agency and assert their varied Japanese-American identities. This fits with the arguments of Dusselier (2002) and Tamura (2002), whose research found that internees were able to find ways to take agency despite the constrictions of the camps. In addition to this, it fits with the arguments of Mbembe (2003) and de Certeau (1984), finding that those bearing the 
weight of necropolitical power can take agency in engaging in stylization and tactics that utilize the spaces allotted to them by those in power.

It would be remiss not to note that this study has its limitations. As the first corpus linguistic study of these newspapers, this project is exploratory in nature and limited in scope. Firstly, the search terms used in the preliminary searches were not all analyzed qualitatively in depth. In the future, I think that these terms would merit further investigation. In particular, I found the words related to religion to offer interesting insight into the valuing of religion, how it fit into the lives of the internees, and how the religions coexisted. A look into religious identity in the camps could become a study of its own. Secondly, this study did not seek to analyze articles, discursive techniques, and portrayals of identity diachronically. This, too, may reveal interesting insights into how the newspaper changed in different phases of the internment and under different head editors.

If corpus linguistic approach studies on this data were to expand past this initial exploratory stage, I see a vast number of directions for expansion in investigations. A more large-scale future direction would be the expansion of this corpus to be representative of all available internment camp newspapers as every camp had a newspaper for all or part of the internment. Having a corpus that includes sub-corpora of multiple camp newspapers would allow the opportunity to compare discursive techniques, identity portrayal, and tactics used throughout internment camp newspapers. Additionally, this larger corpus would allow findings to be more generalizable to all camps as opposed to just the Manzanar Internment Camp. Another avenue for expansion in this research would be using a specially-written program that can give insight into some of the multivariate relationships among the language features in the newspapers. This 
would allow much insight and open up new areas of both quantitative and qualitative research on internment camp newspaper data.

This present study, as well as these potential future studies, can contribute much to the existing literature on Japanese-American internment camps. Linguistics has much that it can bring into the scholarly discussion on Japanese-American internment camps, including principled data approaches from corpus linguistics and a focus on connecting linguistic data to critical theory from critical discourse analysis. By applying a linguistic perspective to these newspapers, we have the ability to shed some light on this topic in U.S. history too often kept in the dark, illuminating the ways that disempowered Americans of the past and present can maintain agency and identity. 


\section{References}

Baker, P., \& Levon, E. (2015). Picking the right cherries? A comparison of corpus-based and qualitative analyses of news articles about masculinity. Discourse \& Communication, 9(2), 221-236. https://doi.org/10.1177/1750481314568542

Bock, Z., \& Hunt, S. (2015). 'It's just taking our souls back': Discourses of apartheid and race. Southern African Linguistics and Applied Language Studies, 33(2), 141-158. https://doi.org/10.2989/16073614.2015.1056196

de Certeau, M. (1984). The practice of everyday life. University of California Press.

Dusselier, J. (2002). Does food make place? Food protests in Japanese American concentration camps. Food and Foodways, 10(3), 137-165. https://doi.org/10.1080/07409710213923

Kessler, L. (1988). Fettered freedoms: The journalism of World War II Japanese internment camps. Journalism History, 15(2-3), 70-79. https://doi.org/10.1080/00947679.1988.12066665

Korematsu v. United States. 324 U.S. 214. (1944).

Mbembé, J.-A. (2003). Necropolitics. Public Culture, 15(1), 11-40.

McEnery, A., \& Baker, H. (2016). Corpus linguistics and 17th-century prostitution: Computational linguistics and history. Bloomsbury Academic. https://library.oapen.org/handle/20.500.12657/31700

Mizuno, T. (2001). The creation of the "free" press in Japanese-American camps: The War Relocation Authority's planning and making of the camp newspaper policy. Journalism \& Mass Communication Quarterly, 78(3), 503-518. https://doi.org/10.1177/107769900107800307

Mizuno, T. (2003). Government suppression of the Japanese language in World War II assembly camps. Journalism \& Mass Communication Quarterly, 80(4), 849-865. https://doi.org/10.1177/107769900308000407

Pennycook, A. (2001). Critical applied linguistics: A critical introduction. Routledge.

Tamura, A. H. (2004). Gardens below the watchtower: Gardens and meaning in World War II Japanese American incarceration camps. Landscape Journal, 23(1), 1-21. https://doi.org/10.3368/lj.23.1.1

Teo, P. (2000). Racism in the news: A critical discourse analysis of news reporting in two Australian newspapers. Discourse \& Society, 11(1), 7-49. https://doi.org/10.1177/0957926500011001002 
Wilkinson, M. (2019). 'Bisexual oysters': A diachronic corpus-based critical discourse analysis of bisexual representation in The Times between 1957 and 2017. Discourse \& Communication, 13(2), 249-267. https://doi.org/10.1177/1750481318817624 